\title{
Assessment of stress in relation to sheep shearing by using behavioural and physiological measurements
}

\author{
H.H. Emeash, A.S. Mostafa and N. M. Abdel-Azem \\ Department of Hygiene, Management and Zoonoses, Faculty of Veterinary Medicine, Beni-suef \\ University, Beni-Suef 62511, Egypt.
}

\begin{abstract}
This study was carried out in Sids Agricultural Research Station belonging to Animal Production Research Institute in Beni-Suef governorate on a total number of forty apparently healthy ewe lambs with average weight of $28 \pm 0.5 \mathrm{~kg}$ to clarify the effect of shearing as a stressor on comfort, feeding and social behaviour and blood cortisol level. Ewe lambs were divided into three groups, the first one $(n=10)$ is shorn at spring, the second $(n=10)$ is shorn in autumn and the third $(n=20)$ is kept as a control. Results showed that there was no significant difference in patterns of comfort behaviour between shorn and unshorn ewes except for grooming behaviour which was significantly $(\mathbf{p}<0.01)$ increased in shorn than unshorn groups. Blood cortisol level was significantly $(p<0.05)$ higher in ewes shorn in spring and autumn at time of shearing (zero minute) than pre-treatment (-20 minutes) and post-treatment time ( 3 hours following shearing). So the cortisol measurements is a useful indicator of short-term stresses from handling or husbandry procedures such as shearing.
\end{abstract}

Stress is the biological response elicited when an individual perceives a threat to its homeostasis (Moberg, 2000). The individual tries to relieve stress and keep homeostasis by avoiding it through its behaviour response or the alteration of various physiological and biochemical response to readjust animal's biology for possible new state of homeostasis with a different set-point (Yousef, 1988). This is carried out through a homeostatic mechanism including the transmission of the stressors to the hypothalamus via the neurotransmitters and the hypothalamus will enhance the various body systems (neuroendocrine, immune and autonomic nervous) and behaviour (Yousef, 1988).

Shearing is necessary for the well-being of sheep, but it is also stressful. Some behavioural changes including comfort behaviour can occur immediately after shearing (da Costa, 1992; Benjamin and Patricia, 2004). Moreover, corticoid levels will increase regardless of the method used, and it is believed that noise, heat, and contact of the shear are responsible for this reaction (Rushen and Congdon, 1986; Hargreaves and Hutson, 1990a; Gonyou, 1997;
Samaha et al., 1999; Fayed 2001; Pawelek and Croney, 2003) while Symonds et al., (1986) found no effect for shearing on cortisol level.

The aim of this study was to investigate the stressful effect of shearing on sheep behaviour and blood cortisol level.

\section{Materials and methods}

This study was carried out in Sids Agricultural Research Station belonging to Animal Production Research Institute in BeniSuef governorate.

Animal and management. The flock consists of 175 ossimi and 145 saidi sheep which are housed in open fronted pens with a stocking density of 1.5 to $2 \mathrm{~m}^{2} /$ head. Sheep were fed on a processed feed in addition to hay and straw and watered twice daily in the morning and late afternoon. A total number of forty apparently healthy ewe lambs with average weight of $28 \pm 0.5 \mathrm{~kg}$ between first and second shearing were divided into three groups, the first one $(\mathrm{n}=10)$ is shorn at spring, the second $(\mathrm{n}=10)$ is shorn at autumn and the third $(n=20)$ is kept as a control. Shearing process was performed by the use of hand shears in a clean, dry and roomy place. Each ewe was restrained by tying the fore and hind limbs of the uppermost 
side while the animal was lying on the other side. Shearing was done by the along method beginning from the neck toward the tail which was described by (Outhouse, 1987). Shearing of each ewe was lasting for about 30-45 minutes.

Behaviour recording and measurements. Behavioural patterns were recorded according to (Molony and Kent, 1997) by direct personal observation directly after shearing for 180 minutes with an interval of 2 minutes as a frequency.

The behavioural patterns recorded are comfort behaviour (oral grooming, head shaking, complete body shaking and standing idle), social behaviour (calling, walking and butting) and feeding behaviour (eating concentrates, eating hay or straw and drinking water).

Blood samples and assay. About $5 \mathrm{ml}$ of blood was obtained from the jugular vein of each ewe in a clean dry centrifuge tube before, at the time, 1,2 , and 3 hours after shearing as demonstrated by (Symonds et al., 1986). Samples were left standing for about 15 minutes till complete clotting and put in the refrigerator for 4 hours to aid in clot separation, then centrifuged at 3000 r.p.m. for 15 minutes for serum separation. After that serum is pipetted and put into labled eppindorf tubes and kept by deep freezing at $20^{\circ} \mathrm{C}$ till assayed. Serum samples were analyzed for cortisol hormone by the use of Competitive Colorimetric Immunoenzymatic method described by (Rolleri et al., 1976).

Statistical analysis. Results were statistically analyzed by the use of one way ANOVA and Ttest according to (Snedecor and Cochran, 1989)

\section{Results and Discussion}

It could be recognized from Table (1) that there was no significant difference in the patterns of comfort behaviour of shorn and unshorn ewes except for oral grooming which was significantly $(p<0.01)$ increased in shorn (10.3) than unshorn ewes (1.3).

The same results were obtained by (Benjamin and Patricia, 2004) who reported that immediately after shearing, the skin undoubtedly presents different set of cutaneous stimuli than that in the fully fleeced condition and possibly evokes some grooming or rubbing actions. On the other hand, other behavioural patterns don't differ significantly between shorn and unshorn ewes including complete body shaking and head shaking. Where Da Costa et al., (1992) observed that shearing had no effect on idling time, standing up and lying down of sheep.

Referring to feeding and social behavioural patterns shown in Table (2), it could be declared that behaviour of eating concentrates, eating hay, drinking water, calling, walking and butting do not differ significantly between shorn (7.0), (22.7), (3.0), (1.3), (41.0) and (1.0), and unshorn (8.0), (22.0), (3.7), (1.3), (41.3) and (0.7) for the mentioned patterns respectively. Moreover, Benjamin and Patricia, (2004) observed that when fully fleeced adult wooled sheep were shorn, they engaged in grooming in a pattern and frequency not different from that of hairy sheep. Concerning the level of blood cortisol in shorn ewe lambs, the results displayed in Table (3) denoted that there was a significant $(p<0.05)$ increase in blood cortisol level at the time of shearing $(0$ minute) for ewes shorn in spring $(113.1 \mathrm{ng} / \mathrm{ml})$ and autumn $(160.3 \mathrm{ng} / \mathrm{ml})$ in comparison with the pretreatment (-20 minutes) levels $(26.0 \mathrm{ng} / \mathrm{ml}$ and $31.8 \mathrm{ng} / \mathrm{ml})$ in spring and autumn respectively.

Table (1): Stressful effect of shearing on comfort behaviour of ewe lambs.

\begin{tabular}{lcccc}
\hline Comfort behaviour & $\begin{array}{c}\text { Oral } \\
\text { grooming }\end{array}$ & Head shaking & $\begin{array}{c}\text { Complete body } \\
\text { shaking }\end{array}$ & $\begin{array}{c}\text { Standing } \\
\text { idle }\end{array}$ \\
Groups & $\mathbf{1 0 . 3}{ }^{* *} \pm 0.9$ & $\mathbf{1 . 0} \pm \mathbf{0 . 6}$ & $\mathbf{1 . 7} \pm \mathbf{0 . 3}$ & $\mathbf{3 . 0} \pm \mathbf{0 . 6}$ \\
\hline Shorn & $\mathbf{1 . 3} \pm \mathbf{0 . 3}$ & $\mathbf{1 . 7} \pm \mathbf{0 . 7}$ & $\mathbf{1 . 0} \pm \mathbf{0 . 6}$ & $\mathbf{5 . 3} \pm \mathbf{1 . 3}$ \\
\hline
\end{tabular}

Results are expressed as means \pm standard error (S.E.).

The behavioural patterns were recorded as a frequency.

${ }^{* * *}$ superscript within columns indicates significant difference at $\mathrm{p}<0.01$. 
Table (2): Stressful effect of shearing on feeding and social behaviour of ewe lambs.

\begin{tabular}{lrccccc}
\hline Behavioural & \multicolumn{3}{c}{ Feeding behaviour } & \multicolumn{3}{c}{ Social behaviour } \\
\cline { 2 - 7 } $\begin{array}{l}\text { patterns } \\
\text { Groups }\end{array}$ & $\begin{array}{r}\text { Eating } \\
\text { conc. }\end{array}$ & Eating hay & $\begin{array}{c}\text { Drinking } \\
\text { water }\end{array}$ & Caling & Walking & Butting \\
\hline Shorn & $7.0 \pm 1.2$ & $22.7 \pm 2.3$ & $3.0 \pm 1.0$ & $1.3 \pm 0.7$ & $41.0 \pm 1.5$ & $1.0 \pm 0.6$ \\
Un shorn & $8.0 \pm 1.2$ & $22.0 \pm 1.5$ & $3.7 \pm 0.3$ & $1.3 \pm 0.7$ & $41.3 \pm 0.8$ & $0.7 \pm 0.7$ \\
\hline
\end{tabular}

Results are expressed as means \pm standard error (S.E.)

The behavioural patterns were recorded as a frequency.

Table (3): Average levels of blood cortisol (ng/ml) in shorn ewe lambs in two different shearing seasons.

\begin{tabular}{|c|c|c|}
\hline \multirow{2}{*}{ Time interval } & \multicolumn{2}{|c|}{ Season of shearing } \\
\hline & Spring & Autumn \\
\hline $\begin{array}{l}\text { Before shearing } \\
(-20 \mathrm{~min}) \text { as a control }\end{array}$ & $26.0 \pm 22.9^{\mathrm{c}}$ & $31.8 \pm 4.2^{\mathrm{c}}$ \\
\hline At shearing & $113.1 \pm 50.3^{\mathrm{a}}$ & $160.3 \pm 38.3^{\mathrm{a}}$ \\
\hline 1hour post shearing & $74.3 \pm 47.1^{\mathrm{b}}$ & $91.5 \pm 24.3^{b}$ \\
\hline 2hours post shearing & $69.4 \pm 35.6^{b}$ & $55.7 \pm 40.4^{\mathrm{c}}$ \\
\hline 3hours post shearing & $60.7 \pm 30.1^{b}$ & $28.2 \pm 28.2^{\mathrm{c}}$ \\
\hline
\end{tabular}

Results are expressed as means \pm standard error (S.E.)

a, b, c superscript within columns indicates significant difference at $\mathrm{p}<0.05$.

After that a significant fall in these levels occurs as compared to the time of shearing which becomes $(74.3,69.4$ and $60.7 \mathrm{ng} / \mathrm{ml})$ and $(91.5$, 55.7 and $28.2 \mathrm{ng} / \mathrm{ml}$ ) for ewes shorn in spring and autumn at $1^{\text {st }}, 2^{\text {nd }}$ and $3^{\text {rd }}$ hours post shearing respectively. These results could be related to the emotional stimuli of restraint and contact of shears which stimulate the HPA axis leading to acute cortisol responses which after reaching the peak level, it falls again by negative feed back mechanism. These results are in the same concert with those obtained by (Hargreaves and Hutson; 1990b and Samaha et al., 1999) but disagree with (Symonds et al., 1986 and) who reported that the decline of cortisol to the basal level occurs by 90 minutes after shearing. Additionally, the changes in plasma cortisol concentrations have been used to assess acute distress responses to a wide range of noxious or potentially noxious husbandry practices (Stafford and Mellor, 1993). Moreover, Hargreaves and Hutson (1990a) mentioned that a stress response (elevation in cortisol level) to shearing procedure may indicate a challenge to the welfare of sheep. So the cortisol measurements are a useful indicator of short-term stresses from handling or husbandry procedures such as shearing.

\section{References}

Benjamin, L. H. and Patricia, P. A. (2004): Developmental and hair-coat determinants of grooming behaviour in goats and sheep. Anim. Behav., 67(1):11-19.

Da Costa, M. J.; da Silva, R. G. and de Souza, R .C. (1992): Effect of air temperature and humidity on ingestive behaviour of sheep. Int. J. Biometerol., 36 (4): 218-220.

Fayed, R. H. (2001): Effect of sheep shearing on behaviour, physiology and performance. Egyptian Soc.Anim. Reprod.Fert. $13^{\text {th }}$ Ann.1 Congr. Giza 22-26 Jan., pp. 97-110. Gonyou, H.W. (1997): Sheep and goats. In R.D. Reynnells Eastwood, Eds. Animal Welfare Issues Compendium, pp.118-124.

Hargreaves, A. L. and Hutson, G.D. (1990a): The stress response in sheep during routine handling procedures. Appl. Anim.Behav.Sci., 26:83-90.

Hargreaves, A. L. and Hutson, G. D. (1990b): Changes in heart rate, plasma cortisol and haematocrit of sheep during a shearing procedure. Appl. Anim.Behav.Sci., 26: 91-101.

Moberg, G. P. (2000): Biological response to stress implications for animal welfare. In: The biology of animal stress basic principles, implications for animal welfare pp1, and when stress becomes distress. pp 11-12, CABI Publishing.

Molony, V. and Kent, J.E. (1997): Assessment of acute 
pain in farm animals using behavioural and physiological measurements. J. Anim. Sci., 75: 266-272.

Outhouse, J. B. (1987): Sheep management techniques. PP 405-407. In: Handbook of livestock Management Techniques ed. Battaglia, R.A. and Mayrose, V.B. Surjeet publications, Indian, New Delhi.

Pawelek, R. and Croney, C. (2003): Animal Welfare Understanding and Addressing Issues Related to the Well-being of Livestock. Oregon State University. EM 8826. Rolleri, E.; Zannino, M.; ORiandini, S. and Malvano, R. (1976): Analysis of cortisol. Clin.Chim.Acta, 66:319.

Rushen, J. and Congdon, P. (1986): Relative aversion of sheep to simulated shearing with and without electro-immobilization. Aust. J. Exp. Agric., 26:535-537.
Samaha, H.; Meneeh, I.S. and Mahrous, U.E. (1999): Effects of clipping on behaviour, production and adrenal cortical function in goats. Assiut Vet. Med. J., 41 (81):127-140.

Snedecor, G.W. and Cochran, W.G. (1989): Statistical Methods. $8^{\text {th }}$ ed. Iowa State University Press, Ames, IA

Staffords, K.J. and Mellor, D.J. (1993):Castration, tail docking and dehorning. What are the constraints. Proc. NZ.Soc.Anim. Prod., 53:189-195.

Symonds, M.E.; Bryant, M.J. and Lomax, M.A. (1986): The effect of shearing on the energy metabolism of the pregnant ewe. Br. J.Nut., 56(3):635-643.

Yousef, M.K. (1988): Animal stress and strain definition and measurements. Appl. Anim. Behav. Sci., 16: 119-126.

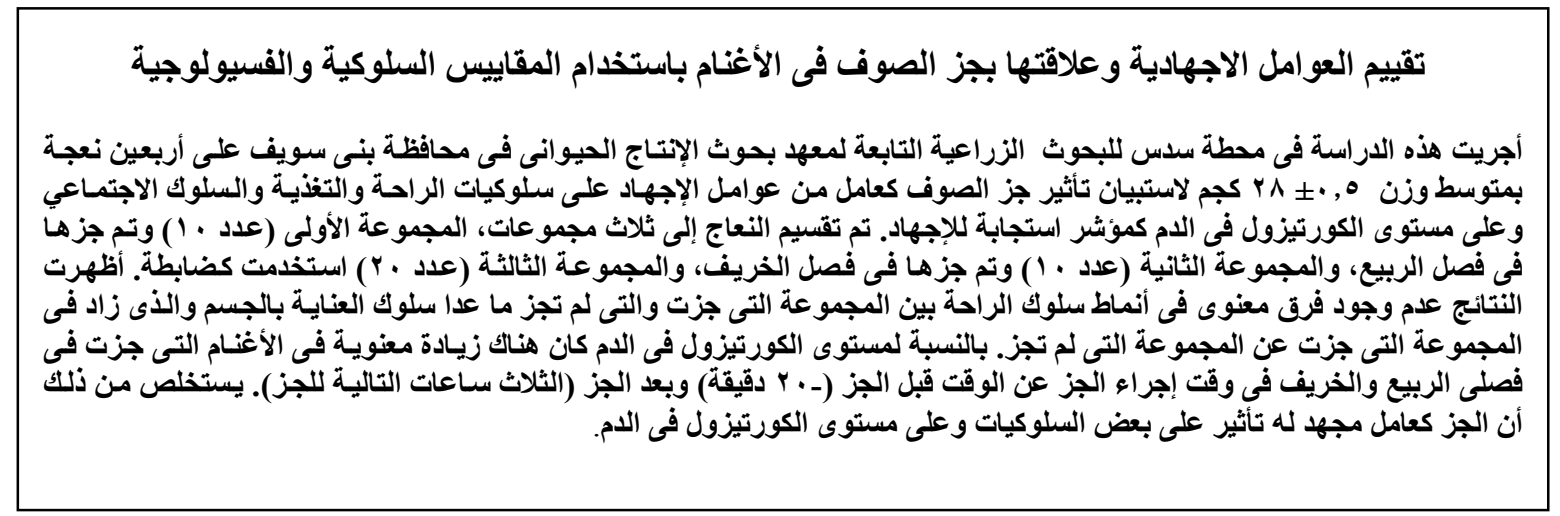

